\title{
HUBUNGAN ANTARA KECEMASAN IBU HAMIL DAN PENGETAHUAN TENTANG VIRUS CORONA DENGAN PEMERIKSAAN RUTIN KEHAMILAN DI BIDAN PRAKTIK MANDIRI BANDAR LAMPUNG
}

\author{
Tiara Rica Dayani ${ }^{1)}$, Oki Suwarsa ${ }^{2)}$, Uni Gamayani ${ }^{3)}$ \\ ${ }^{1}$ Fakultas Kedokteran, Universitas Padjadjaran, Bandung, Indonesia \\ ${ }^{2}$ Departemen Ilmu Kesehatan Kulit dan Kelamin Fakultas Kedokteran, \\ Universitas Padjadjaran/RSUP Dr. Hasan Sadikin, Bandung, Indonesia \\ ${ }^{3}$ Departemen Neurologi Fakultas Kedokteran, Universitas Padjadjaran/ \\ RSUP Dr. Hasan Sadikin, Bandung, Indonesia \\ Email: antiara.rica_dayani@yahoo.co.id
}

\begin{abstract}
ABSTRAK
Wabah COVID-19 menyebabkan krisis global diseluruh Negara. Pandemi ini dengan cepat menyebar oleh sekelompok agen infeksius melalui beberapa metode interaksi dan mengancam kondisi kesehatan. Hal ini membawa dampak terganggunya pelayanan kesehatan maternal dan pemeriksaan rutin kehamilan (ANC) di masa pandemi COVID-19. Angka kematian ibu di Indonesia juga masih cukup tinggi. Salah satu penyebab kematian ibu adalah komplikasi kehamilan yaitu sebesar 15\%. Kesiapan pelayanan berkualitas dalam masa pandemi termasuk pemeriksan rutin kehamilan diperlukan untuk mendeteksi komplikasi pada ibu hamil. Tujuan penelitian ini untuk mengetahui hubungan antara kecemasan ibu hamil dan pengetahuan virus corona dengan pemeriksaan rutin kehamilan. Penelitian ini menggunakan metode studi case control yang merupakan penelitian epidemiologis analitik observasional yang bersifat retrospektif. Pengambilan sampel dengan teknik simple random sampling dengan jumlah sampel 62 orang terdiri dari 31 kasus dan 31 kontrol. Analisis data yang digunakan yaitu analisis univariat dan bivariat dengan uji chi square. Hasil uji statistik chi square menunjukkan bahwa terdapat hubungan antara kecemasan ibu hamil dengan pemeriksaan rutin kehamilan dengan nilai $\mathrm{p}=0,000$ dan terdapat hubungan yang bermakna antara pengetahuan tentang virus corona dengan pemeriksaan rutin kehamilan dengan nilai $\mathrm{p}=0,000$. Kondisi pandemi covid-19 dapat menggangu pemantauan kesehatan ibu dalam pemeriksaan rutin kehamilan sehingga perlu dilakukan penyuluhan dari petugas kesehatan.
\end{abstract}

Kata Kunci: Ibu hamil, Kecemasan, Pemeriksaan Rutin Kehamilan, Pengetahuan, Virus Corona

\begin{abstract}
The COVID-19 outbreak has caused a global crisis throughout the country. This pandemic is rapidly spread by a group of infectious agents through several methods of interaction and threatens health conditions. This has an impact on the disruption of maternal health services and routine pregnancy check-ups (ANC) during the COVID-19 pandemic. The maternal mortality rate in Indonesia is still quite high. One of the causes of maternal death is pregnancy complications, which is $15 \%$. Readiness of quality services during a pandemic. Routine pregnancy check-ups are needed to detect complications in pregnant women. The purpose of this study was to determine the relationship between anxiety of pregnant women and knowledge of the corona virus with routine pregnancy checks. This study uses a case control study method which is an observational analytic epidemiological study that is retrospective in nature. Sampling using simple random sampling technique with a sample size of 62 people consisting of 31 cases and 31 controls. The data analysis used is univariate and bivariate analysis with chi square test. The results of the chi square test showed that there was a relationship between anxiety of pregnant women with routine pregnancy check-ups with $p$ value $=0.000$ and there was a significant relationship
\end{abstract}


between knowledge about the corona virus and routine pregnancy checks with $p$ value $=0.000$. The condition of the COVID-19 pandemic can interfere with maternal health during routine checks, so it is necessary to provide counseling from health workers.

Keywords: Knowledge; Pregnant Women; Corona Virus; Routine Pregnancy Examinations; Antenatal Care

\section{PENDAHULUAN}

Severe Acute Respiratory Syndrome Corona Virus2 (SARS-Cov-2)adalahvirus yang menyerang sistem pernapasan. Virus yang dikenal dengan istilah Covid-19 ini dikonfirmasi di Indonesia pada Maret 2020. Hal ini menjadi fokus utama kesehatan dunia dan juga pemerintah Indonesia karena penyebaran virus yang massif. Gejala umum infeksi Covid-19 yang dirasakan seperti demam, batuk dan sesak nafas. Covid-19 memiliki masa inkubasi 5-14 hari (sejak terpapar). Kasus Covid-19 dengan gejala beratdapat menyebabkan pneumonia, sindrom pernapasan akut, gagal ginjal bahkan kematian.

Penyebaran Covid-19 di Indonesia berdasarkan data yang dirilis oleh tim gugus tugas percepatan penanganan Covid-19 telah mencapai lebih dari dua juta orang terkonfirmasi positif. Pada bulan Juli 2021, Indonesia merupakan negara dengan pertambahan kasus konfirmasi positif tertinggi di dunia yang mencapai 56.757 . Virus Covid-19 ini diketahui dapat menyebabkan komplikasi persalinan seperti aborsi, kelahiran premature, Intra Uterine Growth Restriction (IUGR) dan kematian maternal.

Angka kematian ibu hamil meningkat akibat tidak ditangani dengan baik dan tepat waktu $( \pm 15 \%$ kehamilan akan mengalami komplikasi), diperkirakan angka kematian ibu setiap harinya mencapai angka 830 jiwa di seluruh dunia dan 3 jiwa ibu hamil di Indonesia.Oleh karena itu, sangat diperlukan kesiapan dan pelayanan berkualitas termasuk pemeriksaan rutin kehamilan terhadap ibu hamil dan bersalin. Hal ini agar semua ibu hamil dan bersalin yang mengalami komplikasi dapat memiliki akses pelayanan darurat berkualitas dalam waktu cepat karena sebagian yang mengalami komplikasi memerlukan pelayanan kegawatdaruratan. Ibu hamil yang memiliki pengetahuan yang cukup mengenai kesehatan kehamilan dan mengetahui standar pemeriksaan kehamilan selama menjalani masa kehamilandi masa pandemi lebih tenang dapat menyesuaikan diri dalam situasi saat ini.

Hingga saat ini penelitian terkait Covid-19 pada ibu hamil tentang penularan vertikal ibu ke janin belum dapat dipastikan. Konsekuensi infeksi Covid-19 pada ibu hamil belum diketahui secara pasti karena belum ada bukti yang cukup kuat akantetapi kemungkinan tersebut harus tetap diwaspadai.Pelayanan ANC pada masa pandemi dilaksanakan harus memperhatikan pencegahan penularan Covid-19 baik terhadap ibu, bayi maupun tenaga kesehatan. ANC merupakanpemeriksaan kehamilan yang dilakukan oleh dokter atau bidan untuk mengoptimalkan kesehatan mental dan fisik ibu hamil.

Ibu hamil memiliki risiko terinfeksi Covid19 pada saat memeriksakan kehamilan di pusat fasilitaskesehatan. Hal ini dikarenakanbanyaknya orang yang berkumpul pada waktu yang sama.Risiko bisa bertambah jika sistem penjadwalan pemeriksaan rutinnya kurang baik.Pelayanan kesehatan yang kurang memadai juga dapat terjadi dikarenakan fasilitas kesehatan yang ada saat ini disibukkan dengan pasien Covid19 serta berkurangnya tenaga kesehatan akibat dampak pengurangan jam kerja, kesakitan bahkan kematian. Hal tersebut diatas bisa memicu peningkatan risiko angka kesakitan dan kematian maternalselama dan pasca pandemi Covid-19[5].

Ibu hamil diharapkan memiliki pengetahuan yang cukup dalam menjalani masa kehamilan selama pandemi agar dapat menyesuaikan diri dalam situasi pandemi dan mengerti apa yang akan dilakukan selama menjalani masa kehamilan. Selain itu, ibu hamil akan dapat lebih percaya diri, lebih tenang dalam memeriksakan kehamilan sesuai standar yang diterapkan selama masa pandemik Covid-19. 


\section{METODE}

Metode riset ini menggunakan desainpenelitian analitik observasional. Populasi pada penelitian ini adalah semua ibu hamil trimester III yang hamil di tengah pandemi Covid19dan melakukan pemeriksaan kehamilanyang tercatat dalam buku register ANC di BPS Sulasmi, S.ST Bandar Lampungpada bulan Agustus 2020. Sebanyak 62 orang ibu hamil (31 kasus dan 31 kontrol) yangbersedia menjadi responden penelitian dengan mengisi lembar kuesioner dengan google form secara lengkap. Sampel dalam penelitian ini yaitu kelompok kasus adalahibu yang hamil pada trimester III di tengah pandemi Covid-19 trimester III yang melakukan pemeriksaan kehamilan (1 kali) yang tercatat dalam buku register ANC selama masa pandemi pada bulan maret sampai agustus 2020. Sedangkan kelompok kontrol yaitu ibu yang hamil pada trimester III di tengah pandemi Covid-19 yang melakukan pemeriksaan kehamilan ( $>1$ kali) yang tercatat dalam buku register ANC selama masa pandemi pada bulan Maret sampai Agustus 2020.

Data dianalisis dengan SPSS menggunakan uji Chi-square dan odd ratio (OR). Penelitian mengikuti pedoman etika penelitian kebidann di Fakultas Kedokteran Universitas Padjadjaran dan telah disetujui oleh Komite Etik Penelitian (nomor 755-KEPK).

HASIL

Tabel 1

Karakteristik Ibu Hamil

\begin{tabular}{|c|c|c|c|c|c|c|}
\hline \multirow{3}{*}{$\begin{array}{l}\text { Karakteristik } \\
\text { Responden }\end{array}$} & \multicolumn{4}{|c|}{ ANC } & \multirow[t]{3}{*}{$\mathbf{X}^{2}$} & \multirow[t]{3}{*}{ Nilai $\mathbf{p}^{*}$} \\
\hline & \multicolumn{2}{|c|}{ Kasus } & \multicolumn{2}{|c|}{ Kontrol } & & \\
\hline & $\sum$ & $\%$ & $\sum$ & $\%$ & & \\
\hline \multicolumn{7}{|l|}{ Usia } \\
\hline $20-35$ & 28 & 58,2 & 25 & 47,2 & 97,811 & 0,000 \\
\hline$<20$ and 35 & 3 & 33,3 & 6 & 66,7 & & \\
\hline \multicolumn{7}{|l|}{ Status Pekerjaan } \\
\hline Bekerja & 7 & 58,3 & 5 & 47,1 & 96,640 & 0,000 \\
\hline Tidak Bekerja & 26 & 52 & 24 & 48 & & \\
\hline \multicolumn{7}{|l|}{ Pendapatan } \\
\hline Baik & 16 & 48,5 & 17 & 51,5 & 96,963 & 0,000 \\
\hline Kurang & 15 & 51,7 & 14 & 48,3 & & \\
\hline \multicolumn{7}{|l|}{ Pendidikan } \\
\hline SMP & 0 & 0 & 0 & 0 & 96,000 & 0,000 \\
\hline SMA & 31 & 100 & 31 & 100 & & \\
\hline Jumlah & 31 & 100 & 31 & 100 & & \\
\hline
\end{tabular}

Keterangan: Uji Chi Suare; * $p<0,05$

Tabel 2

Pengetahuan tentang virus corona dengan pemeriksaan rutin kehamilan

\begin{tabular}{|c|c|c|c|c|c|c|c|}
\hline \multirow{3}{*}{ Pengetahuan } & \multicolumn{4}{|c|}{ ANC } & \multirow{3}{*}{ n } & \multirow{3}{*}{$\mathbf{X}^{2}$} & \multirow{3}{*}{ Nilai $\mathbf{p}^{*}$} \\
\hline & \multicolumn{2}{|c|}{ Kasus } & \multicolumn{2}{|c|}{ Kontrol } & & & \\
\hline & $\sum$ & $\%$ & $\sum$ & $\%$ & & & \\
\hline \multirow{2}{*}{$\begin{array}{l}\text { Kurang } \\
\text { Baik }\end{array}$} & 23 & 74,2 & 9 & 29 & 32 & \multirow{3}{*}{$12.658^{\mathrm{a}}$} & \multirow{3}{*}{0,001} \\
\hline & 8 & 25,8 & 22 & 71 & 30 & & \\
\hline \multirow[t]{2}{*}{ Jumlah } & 31 & 32,3 & 31 & 32,3 & 62 & & \\
\hline & & $\alpha=$ & & $=7,02$ & & & \\
\hline
\end{tabular}

Keterangan: Uji Chi Suare; *p $<0,05$

Berdasarkan tabel 1 didapatkan bahwa dari 62 responden, sebagian besar kurang dengan pendidikan SMA. Berdasarkan tabel 2 terlihat bahwa sebagian besar $(74,2 \%)$ ibu hamil pada kelompok kasus memiliki pengetahuan yang kurang mengenai virus corona yang bermakna 
$(\mathrm{p}=0,001)$ dan 7,02 kali lebih kurang dalam melakukan pemeriksaan kehamilan.

Analisis bivariat dilakukan untuk mengetahui keterkaitan antara variable bebas dengan variable terikat. Hal ini untuk mengetahui hubungan antara pengetahuan ibu hamil tentang virus corona dengan pemeriksaan rutin kehamilan dengan menggunakan analisis Chi-Square.

\section{PEMBAHASAN}

Berdasarkan penelitian ini didapatkan hubungan antara pengetahhuan tentang virus corona dengan pemeriksaan rutin kehamilan dengan nilai uji chi square $(\mathrm{p}=0.001)$. Menurut Kemenkes salah satu permasalahan yang dihadapi program kesehatan ibu dan bayi dalam masa pandemi Covid-19 diantaranya adalah pengetahuan ibu dan keluarga terkait Covid-19 dan pelayanan kesehatan bagi ibu dan bayi baru lahir di era pandemi.Pelayanan kesehatan pada ibu hamil merupakan salah satu bentuk pelayanan kesehatan yang terkena dampak langsung oleh adanya pandemi Covid-19, hal ini karena banyak ibu hamil yang merasa cemas dalam melakukan kunjungan pemeriksaan kehamilan untuk memantau kesehatannya.

Pengetahuan merupakan faktor yang sangat penting terbentuknya perilaku seseorang salah satunya pada proses pengambilan keputusan. Seseorang yang memiliki pengetahuan yang baik tentang sesuatu hal, maka ia akan cenderung mengambil keputusan yang lebih tepat berkaitan dengan masalah tersebut dibandingkan dengan mereka yang pengetahuannya rendah[9].

Pengetahuan tentang virus corona yang memadai serta pemeriksaan rutin kehamilan (antenatal care) bagi ibu hamil merupakan dua hal yang harus diketahui ibu hamil pada masa pandemi terutama ibu hamil yang berada pada trimester ketiga. Selain karena perubahan pada tubuh dan sistem imunitas ibu hamil, mereka yang terinfeksi juga akan mengalami dampak yang cukup parah karena beberapa penyakit infeksi saluran pernapasan. Hingga saat ini masih dilakukan penelitian untuk memahami dampak infeksi Covid-19 pada ibu hamil. Data yang tersedia masih terbatas sehingga ibu hamil menjadi populasi yang lebih berisiko terkena penyakit hingga komplikasi dibandingkan populasi umumnya.Ibu hamil perlu untuk terus memperbaharui informasi melalui penyedia layanan kesehatan.
Berdasarkan hasil penelitian sebanyak $60 \%$ ibu hamil kurang mengetahui tentang pencegahan penularan Covid-19 selama kehamilan.Hal ini perlu diperhatikan karena masih tingginya angka kematian dan kesakitan ditambah dengan adanya pandemi Covid-19.Banyak ibu hamil juga belum menerapkan pola hidup bersih dan sehat, kondisi ini akan menyebabkan meningkatnya morbiditas dan mortalitas pada ibu dan bayi baru lahir.

Menurut rekomendasi WHO pemeriksan rutin kehamilan pada ibu hamil trimester III dilakukan sebanyak $>1$ kali sehingga ibu hamil dengan gejala Covid-19 harus diprioritaskan untuk menjalani pemeriksaan.Perlu adanya protokol dan kelayakan pemeriksaan pada setiap fasilitas kesehatan serta penyediaan informasi yang baik agar ibu hamil tidak merasa khawatir terhadap kehamilannya.Ibu hamil membutuhkan pengetahuan kesehatan yang sesuai dengan kondisinya.

Hasil survey Radio Republik Indonesia (RRI) bersama lembaga survey Indo Barometer menunjukkan tingginya tingkat kekhawatiran masyarakat virus corona yakni mencapai $68 \%$. Peneliti Indo Barometer Asep Saepudin berasalasan kecemasan tersebut lebih disebabkan karena pengetahuan mereka yang berasal dari berbagai berita bahwa penularan virus sangat mudah, hingga saat ini belum ditemukan obat yang diproduksi secara masal di dunia hingga dapat menyebabkan kematian.

Hal ini sejalan dengan sebuah penelitian mengenai peran lembaga informasi yang menjadi jembatan penghubung antara kebutuhan terhadap pengetahuan dengan sebaran informasi yang tidak terhitung lagi jumlahnya.Pemberitaan yang terus menerus, kabar yang simpang siur serta munculnya ribuan tulisan tentang virus corona diinternet menambah kekhawatiran terhadap kebenaran kandungan informasi.Data yang valid dan informasi yang ril dibutuhkan agar menjadi sumber pengetahuan yang terpercaya.Diperlukan usaha penyebaran pengetahuan agar bisa mengedukasi masyarakat terutama ibu hamil sebagai populasi yang lebih rentan terhadap serangan virus corona.Ibu hamil trimester III khususnya dinilai memiliki kondisi yang kurang stabil dibandingkan wanita yang tidak hamil. Dapat dipahami bahwa kebutuhan akan pengetahuan tentang virus corona menjadi penting pada masa pandemi Covid-19. 
Kegiatan berupa penyuluhan terhadap masyarakat terutama ibu hamil dengan pendekatan jaringan ataupun kunjungan rumah dapat diterapkan pada masa pandemi Covid19.Kegiatan lainnya juga dapat dilakukan dengan mitra langsung atau dengan membagikan video atau link youtube video melalui whatsapp group yang telah dibuat oleh mitra ataupun buku yang diserahkan langsung oleh mitra kepada ibu hamil.Ibu hamil akan mendapatkan pengetahuan baru tentang virus corona serta cara pencegahan penularan Covid-19 selama masa kehamilan. Perlu dilakukan edukasi mengenai protokol kesehatan seperti mencuci tangan dan memakai masker. Kegiatan dengan pendampingan ibu hamil yang mengalami risiko tinggi sangat diperlukan mengingat masa kehamilan merupakan masa rentan yang perlu untuk diberikan perhatian khusus guna menjaga kesehatan ibu hamil.

Penelitian ini sesuai dengan teori yang menyatakan bahwa kelengkapan ANC ibu hamil salah satunya dipengaruhi oleh pengetahuan ibu hamil.Diketahui bahwa ibu hamil yang memiliki pengetahuan yang rendah akan mempengaruhi kunjungan K4 ANC dan pengetahuan ibu hamil tentang virus corona merupakan hal yang dapat mempengaruhi kondisi psikologis ibu hamil.Hal inilah kemungkinan yang juga menjadi salah satu peneyebab penurunan frekuensi pemeriksaan rutin kehamilan saat pandemi Covid-19 di BPM Sulasmi SST Bandar Lampung.Pengetahuan merupakan faktor yang sangat penting terbentuknya perilaku seseorang salah satunya pada proses pengambilan keputusan. Seseorang yang memiliki pengetahuan yang baik tentang sesuatu hal, maka akan cenderung mengambil keputusan yang lebih tepat berkaitan dengan masalah tersebut dibandingkan dengan mereka yang pengetahuannya rendah.

\section{SIMPULAN DAN SARAN}

Terdapat hubungan antara pengetahuan ibu hamil tentang virus corona dengan pemeriksaan rutin kehamilan ( $\mathrm{p}=0,001$ dan $\mathrm{OR}=7,02)$. Kondisi pandemic Covid-19 dapat menggangu pemantauan kesehatan ibu dalam pemeriksaan rutin kehamilan sehingga perlu dilakukan penyuluhan dari petugas kesehatan.

\section{DAFTAR PUSTAKA}

A. N. Yahya, "Survei RRI-Indo Barometer:
Tingginya kekhawatiran warga atas wabah Covid-19," Kompas.com, Jakarta, Mar. 20, 2020.

B. Mizrak Sahin and E. N. Kabakci, "The experiences of pregnant women during the Covid-19 pandemic in Turkey: A qualitative study," Women birth J. Aust. Coll. Midwives, vol. 34(2), pp. 162-169, 2021, doi: https://doi.org/10.1016/j.wombi.2020.09. 022.

CDC, “Coronavirus Disease 2019.," 2020. https://www.cdc.gov/coronavirus/2019ncov/index.html.

I. Ariawan, "Pandemi Covid-19 dan Dampaknya pada Kesehatan Maternal di Indonesia," 2020.

Kementerian Kesehatan RI, Profil Kesehatan Indonesia Tahun 2020. Jakarta: Kemenkes, 2020.

L. Indrawati and M. B. Karo, "Studi Pengetahuan, Sikap Masyarakat Terhadap Prilaku Pencegahan Penyebaran Covid-19," 0000, 2020. [Online]. Available: http://sinta.ristekbrin.go.id/covid/peneliti an/detail/425.

M. K. Mulyani E, Sulastri, Hidayati Z, "Penguatan Pemahaman Ibu Hamil Tentang Pencegahan Penularan Covid-19 Selama Kehamilan," Univ. Muhammadiyah Gresik, vol. 3(2), pp. 282-386.

N. N. Rosyidah, "Gambaran Tingkat Kecemasan Ibu Primigravida Trimester III dalam Menghadapi Persalinan di BPM Ny.Roidah, SST Desa Dlanggu Mojokerto," J. Keperawatan dan Kebidanan, vol. 7, no. 2, pp. 81-86, 2017.

N. Rachmita, "Tingkat Kecemasan Ibu Hamil Primigravida Trimester Ketiga di Puskesmas Kecematan Tamalanrea," Universitas Hasanuddin, 2017.

Q. E. Adnani and D. R. Pangestuti, Buku Digital Adaptasi Kebiasaan Baru dalam Kebidanan di Era Pandemi Covid-19 Edisi 2. Kota Malang: CV Penulis Cerdas Indonesia, 2021.

R. Nurislaminingsih, "Layanan Pengetahuan tentang Covid-19 di Lembaga Informasi Fakultas Ilmu Komunikasi Universitas Padjadjaran Bandung," J. Ilmu Perpust. dan Inf., vol. 4, no. 1, pp. 1-19, 2020.

Satuan Tugas Penanganan Covid-19, "Rentan 
Terinfeksi Covid-19: Panduan Pemeriksaan Kehamilan di Era Pandemi Covid-19." http://covid19.go.idilovelife.co.id/.

US National Library of Medicine National Institutes of Health, "Corona virus," 2020.

WHO, Maternal Mortality Rate, Global Key Facts Maternal Mortality Rate Report 2019.
Geneva, 2019.

WHO, WHO recommendations on antenatal care for a positive pregnancy experience. Geneva Switzerland: WHO Library Data, 2016. 